\title{
$\mathrm{YBa}_{2} \mathrm{Cu}_{3} \mathrm{O}_{x}$ 超伝導体の微構造が臨界電流密度に及ぼす影響
}

\author{
水谷惟恭・南條敦・篠㟝和夫 ·加藤誠軌 - 増田宏* \\ $\left(\begin{array}{c}\text { 東京工業大学工学部無機材料工学科, } 152 \text { 東京都目黒区大岡山 2-12-1 } \\ \text { * 東英工業 (株), } 194 \text { 東京都町田市忠生 1-8-13 }\end{array}\right.$

\section{Effects of Microstructure on the Critical Current Density of Superconducting $\mathrm{YBa}_{2} \mathrm{Cu}_{3} \mathrm{O}_{x}$}

\author{
Nobuyasu MIZUTANI, Atsushi NANJYO, Kazuo SHINOZAKI, Masanori KATO and Hiroshi MASUDA* \\ $\left(\begin{array}{l}\text { Department of Inorganic Materials, Faculty of Engineering, Tokyo Institute of Technology, } \\ \text { 2-12-1, O-okayama, Meguro-ku, Tokyo } 152 \\ \text { * Toei Industry Co. Ltd., 1-8-13, Tadao, Machida-shi, Tokyo } 194\end{array}\right)$
}

The influences of microstructure on the critical current density of a high $T_{c}$ superconductor $\mathrm{YBa}_{2} \mathrm{Cu}_{3} \mathrm{O}_{x}$ were discussed on the basis of $J_{C_{\text {. }}}$ measured by the standard four-probe resistive method as well as of $J_{c_{\cdot M}}$ calculated from the magnetization curve at $77 \mathrm{~K}$. The microstructure was changed by controlling the sintering temperature and cooling rates. For the specimens sintered at $920^{\circ}-960^{\circ} \mathrm{C}, J_{c_{\text {. }}}$ increased and the resistivity decreased as the bulk density increased. A decrease in $J_{C_{\cdot R}}$ for the specimen sintered at $990^{\circ} \mathrm{C}$ resulted from the incongruent melting of $\mathrm{YBa}_{2} \mathrm{Cu}_{3} \mathrm{O}_{x}$. For the specimens sintered at $990^{\circ}$ to $1030^{\circ} \mathrm{C}, J_{c \cdot R}$ increased again by the recrystallization during slow cooling. The intrinsic $J_{c}$ of $\mathrm{YBa}_{2} \mathrm{Cu}_{3} \mathrm{O}_{x}$ was examined by the Josephson weak links theory from the magnetization data. As a result, the grain size measured with an optical microscope is more suitable compared with the thickness of specimens for the calculation of $J_{c_{\mathrm{m}}}$. Moreover, the area surrounded by weak links is larger than the grain size of the specimens sintered at $940^{\circ}$ to $975^{\circ} \mathrm{C}$. The intrinsic $J_{c}$ calculated from the area surrounded by the weak links was almost constant, $2.5 \times 10^{4} \mathrm{~A} \cdot \mathrm{cm}^{-2}$ at $0.7 \mathrm{kOe}$ at the sintering temperature from $960^{\circ}$ to $1030^{\circ} \mathrm{C} . J_{C . R}$ increased by changing the cooling process from $1030^{\circ} \mathrm{C}$. This is due to the increase in the area surrounded by the weak links corresponding to the grain growth.

[Received May 25, 1989; Accepted July 14, 1989]

Key-words : Superconductor, $\mathrm{YBa}_{2} \mathrm{Cu}_{3} \mathrm{O}_{x}$, Critical current density, Magnetization measurement, Microstructure, Sintering condition

\section{1. 緒 言}

セラミック超伝導体の超伝導特性は, 焼結体の微構造 に大きく依存する. $\mathrm{YBa}_{2} \mathrm{Cu}_{3} \mathrm{O}_{x}$ 超伝導体の臨界電流密 度は, 酸素欠損量 ${ }^{1)}$, 粒界における第二相の析出 ${ }^{2), 31}$, 粒 界における結晶軸のずれ ${ }^{4)}$, 格子欠陥などの微小領域に おける欠陥 ${ }^{4}$ 等によって大きく変化することが順次明ら かにされつつある. しかしながら, 抵抗法から求めた臨 界電流值は焼成温度とともに増加する ${ }^{5)}$ という報告や高 温では $\mathrm{YBa}_{2} \mathrm{Cu}_{3} \mathrm{O}_{x}$ の分解溶融のために粒界に異相が析 出し臨界電流值は低下する ${ }^{6) ~ 8) ~}$ 等の異なる報告がある.

また, $\mathrm{YBa}_{2} \mathrm{Cu}_{3} \mathrm{O}_{x}$ の場合, 結晶粒界がジョセフソン弱 結合を形成していることはよく知られている ${ }^{9)}$.このた め磁化測定から焼結体の臨界電流值を求めるにあたって は, 試料の厚さを用いる方法 ${ }^{10)}$, 13), 侵入深さを用いる 方法 ${ }^{14)}$ や粒径を用いる方法 ${ }^{15}$ 等が提案されている. 更に, 磁化測定から求めた臨界電流值は主に粒内電流によるも のであるとの報告(16)や, 最近では, $\mathrm{YBa}_{2} \mathrm{Cu}_{3} \mathrm{O}_{x}$ 粉末の 磁化測定から, 臨界電流の大部分は粒界を通って流れる ことができないとの報告もある ${ }^{17)}$. 本研究では，焼成温 度を変化させたときの臨界電流密度と焼結体の微構造変
化との関係を検討した. 更に, 抵抗法から求めた臨界電 流值が粒界に強く依存すること, また, 磁化測定から臨 界電流密度を求めるには, 基本的には粒径を用いること は適切であるが, 比較的低い焼成温度の場合は, 弱結合 で囲まれた領域は粒径より数倍大きいことがわかった.

\section{2. 実験方法}

$\mathrm{YBa}_{2} \mathrm{Cu}_{3} \mathrm{O}_{x}$ の合成には $\mathrm{BaCO}_{3}$ (和光純薬工業製, $99 \%$ ), $\mathrm{Y}_{2} \mathrm{O}_{3}$ (三菱化成製, $99.99 \%$ ) 及び $\mathrm{CuO}$ を用い た. $\mathrm{CuO}$ は $\mathrm{Cu}_{2} \mathrm{O}$ (和光純薬工業製) を $950^{\circ} \mathrm{C}$ で 5 時間, 空気中で酸化して得た. 各々の原料粉末を金属元素比で $\mathrm{Y}: \mathrm{Ba}: \mathrm{Cu}=1: 2: 3$ となるように精科し, 磁製乳鉢 を用いてメ夕ノール中で湿式混合した。乾燥粉末を酸素 中, $940^{\circ} \mathrm{C}$ で 15 時間仮焼した。仮焼粉を粉砕し，幅 $3 \mathrm{~mm} \times$ 厚さ $2 \mathrm{~mm} \times$ 長さ $30 \mathrm{~mm}$ の棒状に成形した.これ を酸素中, $920^{\circ} \sim 1030^{\circ} \mathrm{C}$ まで各温度で 10 時間焼成後, 室温まで $1.67^{\circ} \mathrm{C} / \mathrm{min}$ で徐冷して焼結体を得た。

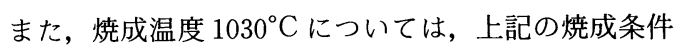
の試料のほかに徐冷の条件を変えた試料を 2 種類作製し た. 試料 $1030 \mathrm{~A}$ は, $1030^{\circ} \mathrm{C}, 10$ 時間焼成後, $800^{\circ} \mathrm{C}$ ま 
で $0.38^{\circ} \mathrm{C} / \mathrm{min}$ で徐冷, $800^{\circ} \mathrm{C}$ で 5 時間保持後, $1.67^{\circ} \mathrm{C} / \mathrm{min}$ で室温まで徐冷した。試料 $1030 \mathrm{~B}$ は, $1030^{\circ} \mathrm{C}, 10$ 時間焼成後, $900^{\circ} \mathrm{C}$ まで $13^{\circ} \mathrm{C} / \mathrm{min}$ で冷却, $900^{\circ} \mathrm{C}$ で 5 時間保持後, $1.67^{\circ} \mathrm{C} / \mathrm{min}$ で室温まで徐冷し た。

作製した焼結試料は真空脱気後, 乾燥窒素ガスを充填 したデシケーター中に保存した. 空気中の水分による劣 化を防ぐため，測定開始直前にデシケーターから試料を 取り出して用いた。得られた焼結体について四端子法に よる臨界温度 $\left(T_{\mathrm{c}}\right)$, 臨界電流密度や抵抗率の測定, 及 び振動試料型磁力計（V.S.M.，東英工業製）を用いて 液体窒素中で磁化測定を行った。

四端子測定は, 縦 $1 \mathrm{~mm} \times$ 横 $1 \mathrm{~mm} \times$ 長さ $15 \mathrm{~mm}$ 程度 に成形した試料体を液体窒素中に浸し, 直流電流を流し て，そのときの電流-電圧特性を測定した。電圧端子間 の電位差が $1 \mu \mathrm{V} / \mathrm{cm}$ となったときの電流を臨界電流密 度 $\left(J_{c_{\mathrm{r}}}\right)$ とした。

微構造は走查型電子顕微鏡 $(\mathrm{SEM})$ や偏光顕微鏡を 用いて観察を行った．相の同定及び格子定数の測定には 粉末X線回折法を用いた.

\section{3. 結果と考察}

\section{1 焼結状態}

焼成温度 $920^{\circ}, 940^{\circ} \mathrm{C}$ においては, $\mathrm{BaCuO}_{2}$ 相等の目 的相以外の反応相の存在が確認された。また，焼成温度 $920^{\circ} \mathrm{C}$ の試料の X線回折図形は全体的にブロードで, 完 全な斜方晶 $\mathrm{YBa}_{2} \mathrm{Cu}_{3} \mathrm{O}_{x}$ ではなかった。焼成温度が $960^{\circ}$ $\sim 1030^{\circ} \mathrm{C}$ の試料では, ほぼ単相の斜方晶 $\mathrm{YBa}_{2} \mathrm{Cu}_{3} \mathrm{O}_{x}$ であった. $\mathrm{YBa}_{2} \mathrm{Cu}_{3} \mathrm{O}_{x}$ は, 酸素中では $990^{\circ} \mathrm{C}$ で分解溶 融する ${ }^{18)}$. したがって焼成温度 $990^{\circ} \mathrm{C}$ 以上の試料は一度 分解溶融した後, 徐冷中に単相に戻ったものと考えられ る.

図 1 に $\mathrm{YBa}_{2} \mathrm{Cu}_{3} \mathrm{O}_{x}$ 焼結体の焼成温度とかさ密度及び 相対密度（理論密度 $6.36 \mathrm{~g} / \mathrm{cm}^{3}$ に対する比）の関係を 示す. 図中点 A，B はそれぞれ試料 $1030 \mathrm{~A} ， 1030 \mathrm{~B}$ で ある. 焼結体の汃密度は, 焼成温度の増加に伴い増加 し， $970^{\circ} \mathrm{C}$ 以上ではほぼ一定となる。また，徐冷条件に よるかさ密度の変化はない。

図 2 に焼結体の試料表面の SEM 写真を示す.焼成温 度 $940^{\circ} \mathrm{C}$ の試料は，多孔質であるが， $960^{\circ} \mathrm{C}$ 以上の試 料は，粒子が密に接触している．また粒子表面には縞状 の模様が観察され，粒成長に液相が関与していることを 示している ${ }^{4), 18)} .975^{\circ} \mathrm{C}$ 以上の試料では結晶の異方性が 大きくなるとともに，粒成長が顕著になる.

$1030^{\circ} \mathrm{C}$ から徐冷した武料 $(1030 \mathrm{~A} ， 1030 \mathrm{~B})$ では, 粒成長とともに, 試料 $1030 \mathrm{~A}$ では粒子内に亀裂が多数

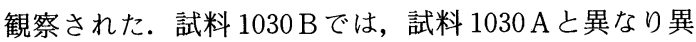
常粒成長した粒子だけに亀裂が観察され，その数も比較
的少なかった.

図 3 に試料 $1030 \mathrm{~A}$ と $1030 \mathrm{~B}$ の偏光䫓微鏡組織を示す. 1030 B は 1030 A に比べて粒径分布が広く, 粗大化した 粒の粒径は, 2 種類の試料でほぼ変わらないものの, 細 かい粒の大きさは $1030 \mathrm{~B}$ の方がかなり小さい. $1030 \mathrm{~B}$ は $1030^{\circ} \sim 900^{\circ} \mathrm{C}$ まで急冷したので粒成長が一部抑制さ れたものと考えられ，図 2 の 1030 Bにおいて亀裂が少 ないのはこの小さい粒のために亀裂の進展が抑えられ， 粗大化した粒の一部だけに亀裂が生じたためと考えられ る.

図 4 に焼成温度と粒径の関係を示す．粒径は各試料の 偏光顕微鏡写真から長軸の長さを測定し, 算術平均值を 粒径とした。.また, この粒径の焼成温度依存性はSEM 観察から得られた結果とよく一致する.

\section{2 超伝導特性}

四端子法による零磁場下での臨界電流密度 $J_{\mathrm{C} \cdot \mathrm{n}}, T_{\mathrm{c}}$ (零 抵抗）と室温での抵抗率の焼成温度依存性を図 5 に示す. 図中で点 $\mathrm{A}, \mathrm{B}$ はそれぞれ試料 $1030 \mathrm{~A}, 1030 \mathrm{~B}$ を示す. 焼成温度 $920^{\circ} \mathrm{C}$ の試料では液体窒素温度までに超伝導 を示さなかったが, 焼成温度 $940^{\circ} \sim 1030^{\circ} \mathrm{C}, 1030 \mathrm{~A}$ 及 び $1030 \mathrm{~B}$ の試料ではいずれも $85 \mathrm{~K}$ 付近の $T_{\mathrm{c}}$ を示した. 粉末 X線回折法による格子定数の測定の結果は, 焼成温 度 $940^{\circ} \sim 1030^{\circ} \mathrm{C}, 1030 \mathrm{~A}, 1030 \mathrm{~B}$ の試料全てにおいて, $a$ 軸 $(3.823 \AA), b$ 軸 $(3.888 \AA), c$ 軸 $(11.676 \AA)$ と もにほとんど変化がみられない，このことから試料間に おける酸素欠損の値や粒内の結晶性に差はないと考えら れる.

室温での抵抗率は焼成温度が $920^{\circ}$ から $940^{\circ} \mathrm{C}$ の間で 急激に減少し, $940^{\circ} \mathrm{C}$ 以上ではほぼ一定になる。しかし $990^{\circ} \mathrm{C}$ では多少抵抗率が増大する。また， $1030 \mathrm{~A}, 1030$ $\mathrm{B}$ は $1030^{\circ} \mathrm{C}$ の試料とほとんど変わらなかった。

$J_{\text {C.R }}$ は, $940^{\circ} \mathrm{C}$ から $960^{\circ} \mathrm{C}$ の間で増大し $960^{\circ} \mathrm{C}$ で最大 值を示したのち, $990^{\circ} \mathrm{C}$ 付近では減少し, $1000^{\circ} \mathrm{C}$ 以上

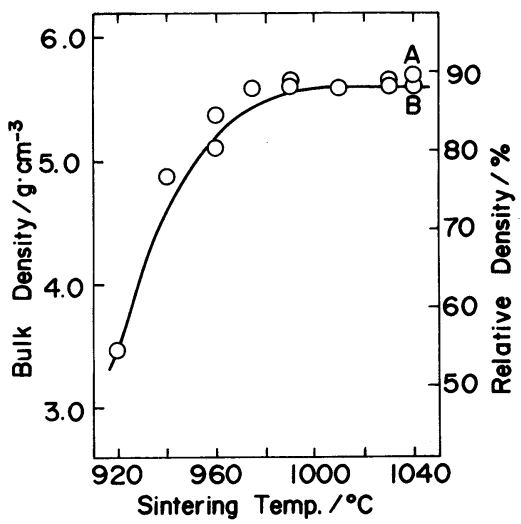

Fig. 1. The bulk density as a function of sintering temperature. $\mathrm{A}$ and $\mathrm{B}$ correspond to the specimens $1030 \mathrm{~A}$ and $1030 \mathrm{~B}$, respectively. 

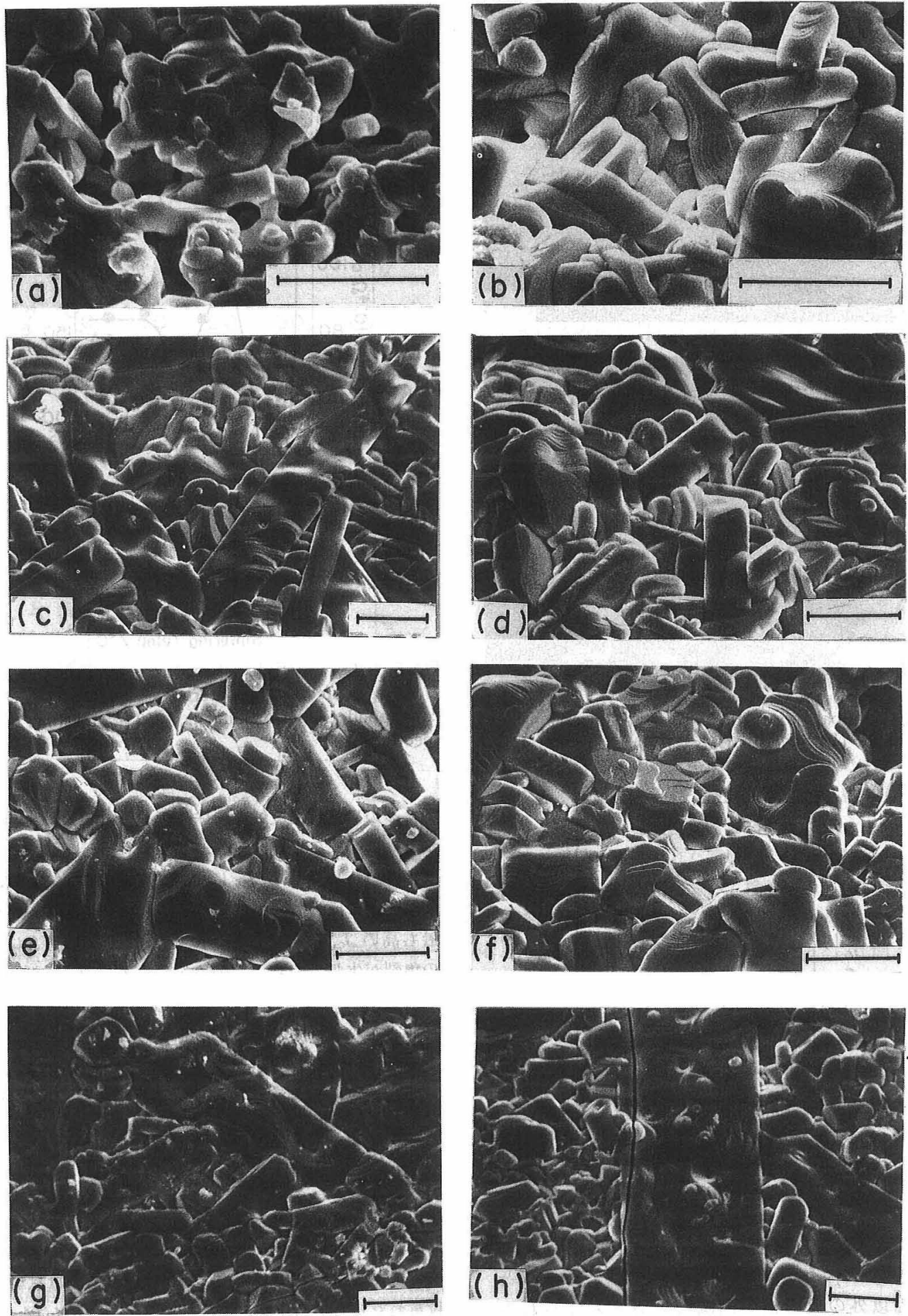

Fig. 2. SEM micrographs of the free surface of specimens sintered at (a) $940^{\circ} \mathrm{C}$, (b) $960^{\circ} \mathrm{C}$, (c) $975^{\circ} \mathrm{C}$, (d) $990^{\circ} \mathrm{C}$, (e) $1010^{\circ} \mathrm{C}$ and (f) $1030^{\circ} \mathrm{C}$, respectively, and of specimens (g) $1030 \mathrm{~A}$ and (h) $1030 \mathrm{~B}$. Bars $=10 \mu \mathrm{m}$ 

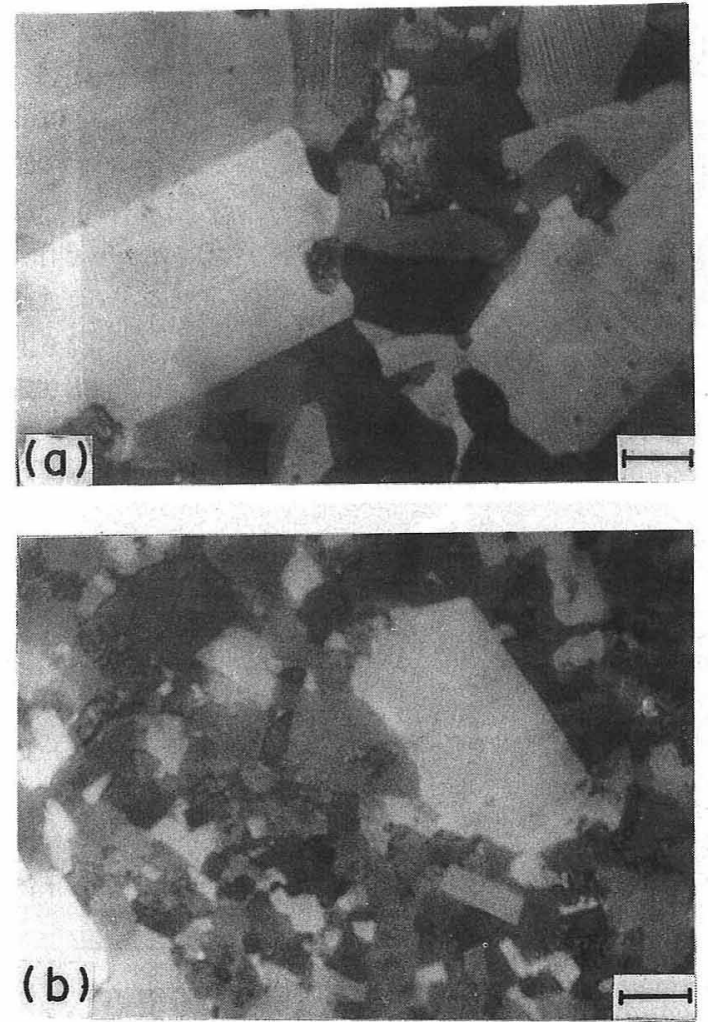

Fig. 3. Optical micrographs of the specimens (a) $1030 \mathrm{~A}$ and (b) $1030 \mathrm{~B}$. Bars $=10 \mu \mathrm{m}$

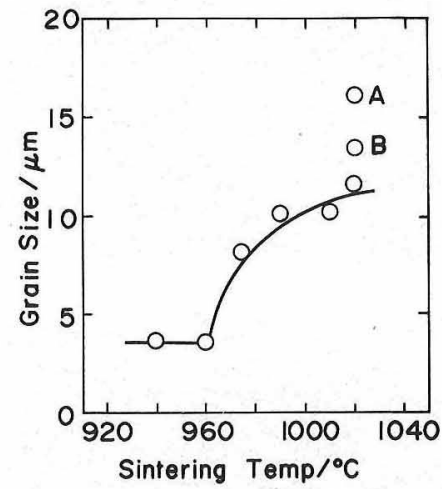

Fig. 4. The grain size as a function of sintering temperature. $\mathrm{A}$ and $\mathrm{B}$ correspond to the specimens $1030 \mathrm{~A}$ and $1030 \mathrm{~B}$, respectively.

では再び増大する複雑な挙動を示す. $960^{\circ} \mathrm{C}$ までの焼成 温度の増加に伴う $J_{\mathrm{C}_{\mathrm{R}}}$ の増加は, 主に試料の緻密化と, 目的相以外の反応相の消滅によると考えられる. $1010^{\circ} \mathrm{C}, 1030^{\circ} \mathrm{C}$ の試料は, 焼成中に一度分解するもの の徐冷中に再び結晶化したと考えられるので，いずれも $960^{\circ} \mathrm{C}$ とほぼ等しい $J_{\mathrm{C}_{\mathrm{p}}}$ の值をとる. 焼成温度 $990^{\circ} \mathrm{C}$ に おける $J_{\mathrm{C}_{\mathrm{R}}}$ の低下, 抵抗率の増加は, 以下のように考え られる.この焼成温度は $\mathrm{YBa}_{2} \mathrm{Cu}_{3} \mathrm{O}_{x}$ の分解溶融温度に
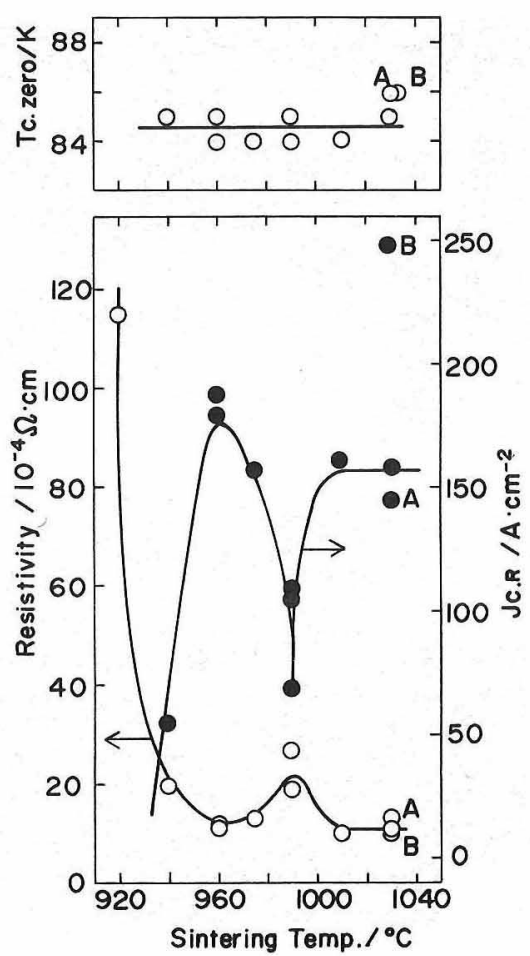

Fig. 5. $T_{\mathrm{c}}$, resistivity at room temperature and $J_{\mathrm{C}_{\mathrm{R}}}$ at $77 \mathrm{~K}$, as a function of sintering temperature. $A$ and $B$ correspond to the specimens $1030 \mathrm{~A}$ and $1030 \mathrm{~B}$, respectively.

あたるので分解温度付近の徐冷が不十分であり, 再結晶 が十分に進まなかったためと考えられる。

$1030 \mathrm{~A}, 1030 \mathrm{~B}$ の $J_{\mathrm{C}_{\mathrm{R}}}$ については, $1030 \mathrm{~A}$ が $1030^{\circ} \mathrm{C}$ の試料とほぼ等しいのに対して，1030Bは測定試料中で 最も高い $J_{\mathrm{C}_{\mathrm{R}}}$ 值を示した。 上述のように $1030 \mathrm{~A}$ は多数 の亀裂が生じており，この亀裂のために $J_{\mathrm{C}_{\mathrm{R}}}$ は低下して いると考えられる.もしこの亀裂が存在しなければ,

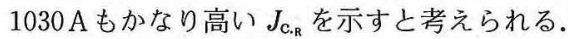

\section{3 磁化測定}

磁化測定から臨界電流密度 $J_{\text {C.M }}$ を求めるには, BeanLondon モデルから

$$
\Delta M=\mu_{0} J_{\text {c. }} d / 2
$$

( $\mu_{0}:$ 真空の透磁率, $d:$ 試料の厚さ) ( 1 )

を用いて求めるのが一般的である.

そこで， $975^{\circ} \mathrm{C}$ で焼成した同一の試料から厚さを変え た 4 種類の試料を切出し, 試料単独, あるいは試料を 2 枚重ねたりして磁化测定を行った. 図6に $\Delta M$ (図6(a)) 及び（1）式を用いて算出した $J_{\mathrm{c}_{M}}$ (図 6(b)) を試料の 厚さ $d$ に対してプロットした。

$\Delta M$ は $0.2 \mathrm{kOe}, 0.7 \mathrm{kOe}$ のどちらにおいても試料の 厚さに比例しないことがわかる. 同様の結果が $\mathrm{YBa}_{2} \mathrm{Cu}_{3} \mathrm{O}_{x}$ 円板について報告されている ${ }^{11)}$. また， $J_{\mathrm{C} \cdot \mathrm{M}}$ 

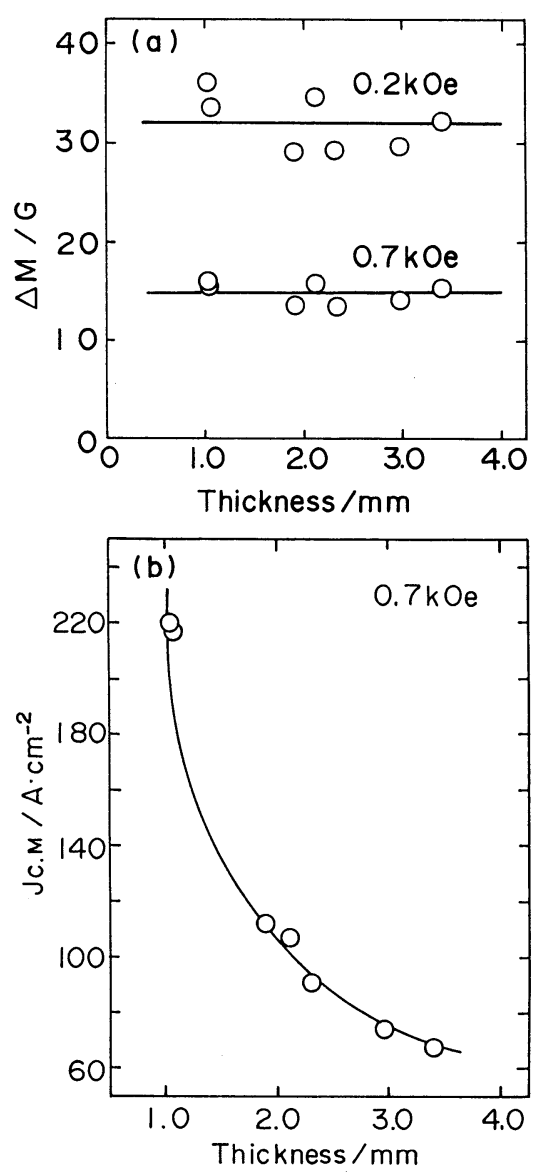

Fig. 6. The dependence of (a) the magnetization loop width, $\Delta M$, on specimen thickness and (b) $J_{\text {c.M }}$ on specimen thickness.

は材料自身の特性であるはずで，厚さにより変化すると いうことは考えにくいが図6(b) より同一試料であって も厚さの減少に伴って変化している. 以上のようなこと から $\mathrm{YBa}_{2} \mathrm{Cu}_{3} \mathrm{O}_{x}$ セラミックスの場合, (1) 式中の $d$ を試料外形の厚さであるとすることには問題があると考 えられる.

$\mathrm{Ni} ら^{16)}$ は磁化測定から求めた $J_{\mathrm{C} . \mathrm{M}}$ は主に粒内の遮へ い電流によるものであると報告している. Shimizu ら ${ }^{17)}$ は, $\mathrm{YBa}_{2} \mathrm{Cu}_{3} \mathrm{O}_{x}$ 粉末を用いた磁化測定により, 大部分 の $J_{\mathrm{C} \cdot \mathrm{M}}$ の電流は粒界によって制限されていると報告して いる. また, $\mathrm{YBa}_{2} \mathrm{Cu}_{3} \mathrm{O}_{x}$ セラミックス中に存在する多 数の結晶粒界が粒界相や結晶軸のずれのために弱結合を

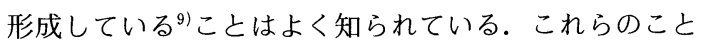
から, 磁化測定から求まる $\Delta M$ は弱結合で囲まれた領 域の局所的な臨界電流値を示している可能性がある。し たがって磁化測定から $J_{\mathrm{c} \cdot \mathrm{M}}$ を求めるには弱結合で囲まれ た領域を的確に求めることが必要になる. 一般に超伝導 セラミックスでは, 粒子がこの範囲を示すものと考えら
れる. そこで, 焼結体の平均粒径と磁化測定から $J_{\mathrm{C} . \mathrm{M}}$ を 求めることを試みた.

図 4 の粒径を用いて計算した， $0.7 \mathrm{kOe}$ 中の $J_{\text {c.m }}$ を図 7 に示す. 得られた $J_{\mathrm{c.m}}$ は磁場をかけているにもかかわ らず図 5 に示した $J_{\text {C.R }}$ に比較してかなり大きくなってい る.この原因は $J_{\text {C.M }}$ が上述のように弱結合の起きていな い領域を流れる電流値であるのに対して $J_{\mathrm{C} \text {. }}$ は焼結体全 体を流れる電流であり結晶粒界及び超伝導弱結合に強く 影響された值であるためである.

$J_{\text {C.M }}$ の焼成温度依存性についてみると $975^{\circ} \mathrm{C}$ までは大 きく変化するのに対して $990^{\circ} \mathrm{C}$ 以上ではほとんだ一定 である. また $940^{\circ} \sim 975^{\circ} \mathrm{C}$ の $J_{\mathrm{C}_{\mathrm{M}}}$ は $990^{\circ} \mathrm{C}$ の $J_{\mathrm{C}_{\mathrm{M}}}$ と比較 して大きくなっており, $960^{\circ} \mathrm{C}$ では, $990^{\circ} \mathrm{C}$ 以上の $J_{\mathrm{c} . \mathrm{m}}$ のほぼ 3 倍の值を示す. $\mathrm{YBa}_{2} \mathrm{Cu}_{3} \mathrm{O}_{x}$ セラミックスの場 合, 一般に臨界電流密度は粒子の配向性, $\mathrm{YBa}_{2} \mathrm{Cu}_{3} \mathrm{O}_{x}$ の酸素欠損量, 粒界の状態, 格子欠陥などの微小領域に おける欠陥等に大きく影響されることが知られている.

配向性については試料断面の SEM 観察から, 酸素欠損 については格子定数の変化から, いずれの試料にもほと んど差異はないと考えられる. 微小領域における欠陥に ついて, 今回は観察していないが，この影響からだけで は $J_{\mathrm{c} . \mathrm{M}}$ 值が大きく変化する現象は説明できない。また焼 成温度 $940^{\circ} \mathrm{C}$ の $J_{\text {c.m }}$ は試料中に未反応相が残っている にもかかわらずかなり大きくなっている．これらの原因 として弱結合で囲まれた領域が偏光顕微鏡で求めた粒径 より大きく，粒径を用いて計算した $J_{\mathrm{C} . \mathrm{M}}$ が見掛け上，大 きくなったという可能性が考えられる.

そこで弱結合で囲まれた領域を，単純に粒子の大きさ と考えることの妥当性について検討する．無秩序な方向 の電流に対する三次元ジョセフソン弱結合モデルを考え ると, 理論的な臨界電流密度は $(\rho \times r)^{-1}$ に比例する ${ }^{19}$.

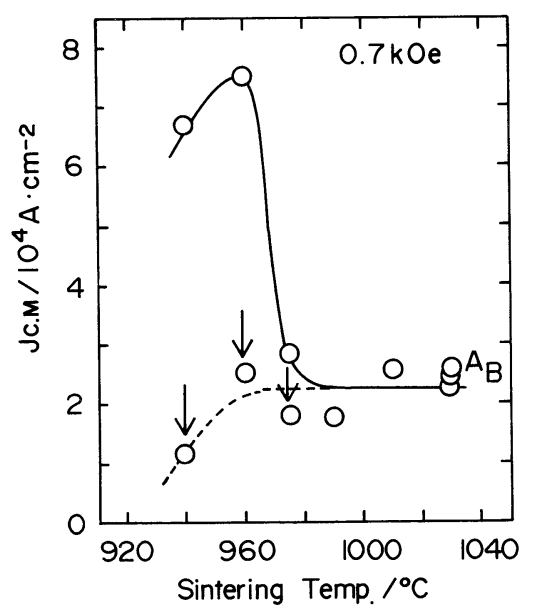

Fig. 7. $J_{\text {C.M }}$ as a function of sintering temperature. The arrows indicate $J_{\text {с. }}$ calculated using the model of weak links. 


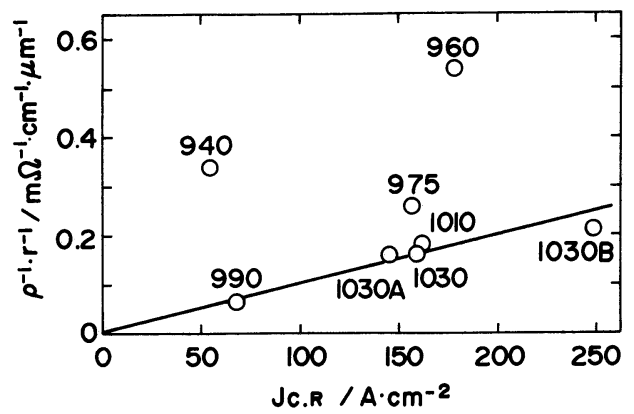

Fig. 8. Relation between $J_{C_{\text {. }}}$ and $\rho^{-1} \cdot r^{-1}$ on the basis of the model of weak links and Equation ( 2 ). $\rho:$ resistivity at onset temperature $r$ : mean grain size from Fig. 4.

$$
J_{\mathrm{c}} \propto(\rho \times r)^{-1}
$$

ここで $\rho$ : 常伝導状態における試料全体の弱結合の抵抗 率, $r$ : 平均粒径である.

いま単位長さ 1 の試料について考えると $1 \gg r$ である から $1 / r$ は単位長さあたりの粒界数を表すことになる. $\rho \times r$ は (弱結合の抵抗率 $) \times(1 /$ 粒界数 $)$ すなわち, 一 粒界当たりの弱結合の抵抗率を示す. 図 8 に $J_{\mathrm{C}_{\mathrm{R}}}$ と $(\rho \times r)^{-1}$ との関係について示す.ここで $\rho$ は超伝導才 ンセット温度における試料の抵抗率とした. 超伝導オン セット温度における試料の抵抗率は実際には, $\mathrm{YBa}_{2} \mathrm{Cu}_{3} \mathrm{O}_{x}$ の抵抗率と弱結合部分の抵抗率の成分を含 んでいる.したがってこれらを分離する必要があるが, このオンセット温度付近では, 弱結合による抵抗率の影 響が大きいと考えられる20)ことからオンセット温度での 抵抗率をそのまま用いた。 またここで用いた $J_{\mathrm{C}_{\mathrm{R}}}, \rho$ は いずれも零磁場中の值である. $r$ は偏光顕微鏡から算 出した平均粒径である. 焼成温度 $940^{\circ}, 960^{\circ}, 975^{\circ} \mathrm{C}$ の 試料を除くと, よく直線上にのっている.この直線を用 いて, 焼成温度 $940^{\circ}, 960^{\circ}, 975^{\circ} \mathrm{C}$ の試料について, $J_{\mathrm{C}_{\mathrm{R}}}$ の值から ( 2 ) 式中の $r$ の值, つまり弱結合によっ て囲まれた領域（以下弱結合径亡する）を求めるとそれ ぞれ $21.1 \mu \mathrm{m}, 11.1 \mu \mathrm{m}, 13.3 \mu \mathrm{m}$ となる.この弱結合 径は偏光顕微鏡からもとめた粒径よりそれぞれ 5.7 倍, 3.0 倍, 1.6 倍大きくなっている.これは, 焼成温度 $990^{\circ} \mathrm{C}$ 以上では弱結合で囲まれた領域は粒径程度である のに対し, $975^{\circ} \mathrm{C}$ 以下では粒子の大きさより大きいこと を示している.つまり, 焼成温度 $940^{\circ} \sim 975^{\circ} \mathrm{C}$ において, 遮へい電流は粒界で完全に遮断されずに, 一部の粒界を 越えて流れていることがわかる．比較的，焼成温度が低 い場合には, 粒界は弱結合を形成しにくい場合があるこ とを示している.

このように粒界の状態が焼成温度によって異なってい る原因は次のように考えられる.この物質は酸素中 $990^{\circ} \mathrm{C}$ 前後において分解溶融する. したがって焼成温度
が分解温度以上であると粒界に異相が析出しやすいと考 えられる. これに対して分解温度以下であると, 部分溶 融はあるものの比較的分解は少なく, 粒界において異相 の析出は少ないと考えられる.

このようにして求めた弱結合径を考慮して焼成温度 $940^{\circ}, 960^{\circ}, 975^{\circ} \mathrm{C}$ の試料について $J_{\text {c.m }}$ 值を計算し直し たものを図 7 に矢印を用いて示す. 修正された $J_{\mathrm{c} \cdot \mathrm{M}}$ の焼 成温度依存性についてみてみると原料の未反応相がある 焼成温度 $940^{\circ} \mathrm{C}$ の $J_{\text {C.M }}$ が比較的低いものの, そのほか の焼成温度ではほとんど変化がないことがわかる．この $J_{\text {C.M }}$ の值そのものは, 微小交流磁場重畳法により求めら れた粒内臨界電流密度の值 ${ }^{16)}$ に近いものとなっている.

徐冷条件を変えた試料についてみてみると試料 1030 $\mathrm{A}$ と試料 $1030 \mathrm{~B}$ の $J_{\mathrm{C} \cdot \mathrm{M}}$ はほとんど変わらない. また焼 成温度 $1030^{\circ} \mathrm{C}$ と比べても徐冷条件を変えることによる $J_{\text {C.M }}$ の変化はほとんど観察されない.つまり粒内は超伝 導電流に対してはほとんど同じ状態であると考えられ

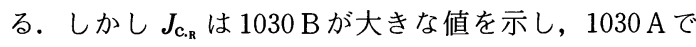
は多数の亀裂があるにもかかわらず焼成温度 $1030^{\circ} \mathrm{C}$ 亡 ほぼ同程度の值である．また試料断面の SEM 観察から は 3 種類のどの試料からも粒子の配向は観察されないこ とから，1030Aに亀裂が存在しなければ $1030 \mathrm{~B}$ と同じ ようなかなり高い $J_{\text {C.R }}$ を示すことが期待される.このこ とから焼成条件の制御等で粒成長させ, 弱結合径を大き くすることは， $J_{\text {C.R }}$ を大きくすると考えられる．しかし 粒成長に伴って亀裂が発生するためこの亀裂を抑えるこ とが重要である。

\section{4. まとめ}

焼成温度 $\left(920^{\circ} \sim 1030^{\circ} \mathrm{C}\right)$ や，徐冷条件を変化させて 作製した $\mathrm{YBa}_{2} \mathrm{Cu}_{3} \mathrm{O}_{x}$ セラミックスの臨界電流密度を測 定し，これと微構造の関係を検討した. その結果を以下 にまとめる.

（1）焼成温度 $960^{\circ} \mathrm{C}$ までの焼成温度の増加に伴っ て $J_{\mathrm{C} . \mathrm{R}}$ は増加, 抵抗率は減少する.これは主に試料の緻 密化, 未反応相の消滅によるものと考えられる. 焼成温 度 $990^{\circ} \mathrm{C}$ では一時的に $J_{\mathrm{C} \cdot \mathrm{R}}$ の低下, 抵抗率の増加がみら れるが，これはこの焼成温度が $\mathrm{YBa}_{2} \mathrm{Cu}_{3} \mathrm{O}_{x}$ の分解溶融 温度にあたるために徐冷中に再結晶が十分に進まなかっ たためと考えられる. 焼成温度 $990^{\circ} \mathrm{C}$ 以上では焼成中 に分解するものの, 徐冷中に再び結晶化するため $J_{\mathrm{C}_{\mathrm{R}} \text { 值 }}$ は再び増加する.

(2) 三次元ジョセフソン弱結合モデルを用いること によって, 弱結合によって井まれた領域（弱結合径）を 計算した. 弱結合径は焼成温度 $940^{\circ} \sim 975^{\circ} \mathrm{C}$ の間では粒 径より大きいのに対して $990^{\circ} \mathrm{C}$ 以上ではほぼ粒径に等 しかった．このように焼成温度により弱結合径が粒径と 一致しないのは, $\mathrm{YBa}_{2} \mathrm{Cu}_{3} \mathrm{O}_{x}$ の分解溶融のため粒界の 
状態が異なるためと考えられる。

（3）弱結合径を用いて磁化曲線から $J_{\text {C.M }}$ 值を算出し た.この $J_{\text {C.M }}$ の焼成温度依存性については, 原料の未反 応相がある焼成温度 $940^{\circ} \mathrm{C}$ で比較的低いものの, その ほかの焼成温度ではほとんど変化がなかった。

（4）焼成温度 $1030^{\circ} \mathrm{C}$ において徐冷条件を変化さ せ，粒成長させた.これにより弱結合径が大きくなり， $J_{\text {C.R }}$ が大きくなった. しかし粒成長に伴って, 亀裂が発 生するためこの亀裂を抑えることが重要である.

\section{文献}

1) S.X. Dou, H. K. Liu, A.J. Bourdillon, N. Savvides, J. P. Zhou and C. C. Sorrell, Solid State Commu., 68, 221-25 (1988)

2）池田省三，小川恵一，表面科学，9，17-21 (1988).

3）木村一弘, 松下明行, 青木晴善, 池田省三, 上原 満, 本多均一, 松本武彦, 小川恵一, 日本金属学会誌, 52, 441-47 (1988).

4）遠藤守信, 宮下克己, セラミック ス論文誌, 97, 1-7 (1989).

5) K. Togano, H. Kumakura, H. Shimizu, N. Irisawa and T. Morimoto, Jpn. J. Appl. Phys., 27, L 45-47 (1988).

6) 松田元秀, 高田雅介, 山下 努, 岡本祥一, 石井 守, 粉体および粉末冶金，35，373-78（1988）.

7) A. Morimoto, T. Maeda, A. Moto, M. Kumeda and T. Shimizu, Jpn. J. Appl. Phys., 27, L 407-10 (1988).

8）山本龍也, 古沢孝幸, 朴 慶浩, M. L. Green, 桑原和幸, 大庭直樹, 長谷川哲也, 岸尾光二, 北澤宏一, 粉体およ
び粉末冶金，35，35-40（1988）.

9) J.W. Ekin, Advan. Ceram. Mater., 2, 3B, 586-92 (1987).

10) H. Kumakura, M. Uehara and K. Togano, Appl. Phys. Lett. , 51, 1557-59 (1987).

11) K. Funaki, M. Iwakuma, Y. Sudo, B. Ni, T. Kisu, T. Matsushita, M. Takeo and K. Yamafuji, Jpn. J. Appl. Phys., 26, L1445-47 (1987).

12) J. L. Tholence, H. Noel, J. C. Levet, M. Potel, P. Gougeon, G. Chouteau and M. Guillot, Physica C, 153-155, 1479-80 (1988).

13) X. Yunhui, G. Weiyan and K. Zeibig, Physica $C$, 153-155, 1657-58 (1988).

14) M. Polak, F. Hanic, I. Hlasnik, M. Majoros, F Chovanec, I. Horvath, L. Krempsky, P. Kottman, M. Kedrova and L. Galikova, Physica C, 156, 79-89 (1988).

15) L.W. Roeland, F. R. Deboer, Y. K. Huang, A. A. Menovsky and K. Kadowaki, Physica C, 156, 717-19 (1988).

16) B. Ni, T. Munakata, T. Matsushita, M. Iwakuma, K. Funaki, M. Takeo and K. Yamafuji, Jpn. J. Appl. Phys., 27, 1658-62 (1988).

17) E. Shimizu and D. Ito, Phys. Rev. B, 39, 2921-23 (1989).

18）南條 敦, 篠㟝和夫, 水谷惟恭, 加藤誠軌, 日本化学会誌, 692-96 (1989).

19) K. Matsumoto, M. Mimura and Y. Tanaka, Workshop on Electric Instrument by the Institute of Electrical Engineers of Japan, Kyoto SA-87-62 (1987).

20) S. W. Tozer, A. W. Kleinsasser, T. Penney, D. Kaiser and F. Holtzberg, Phys. Rev. Lett., 59, 1768-71 (1987). 